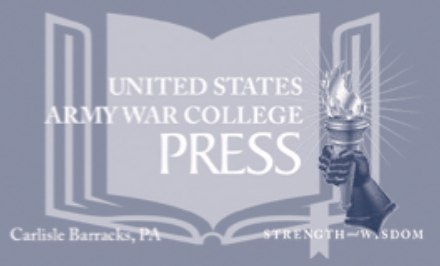

\title{
PROSPECTS FOR IRAN'S NEW DIRECTION
}

\section{Keir Giles}

Strategic Studies Institute

U.S. Army War College, Carlisle, PA 


\section{Report Documentation Page}

Form Approved

OMB No. 0704-0188

Public reporting burden for the collection of information is estimated to average 1 hour per response, including the time for reviewing instructions, searching existing data sources, gathering and maintaining the data needed, and completing and reviewing the collection of information. Send comments regarding this burden estimate or any other aspect of this collection of information,

including suggestions for reducing this burden, to Washington Headquarters Services, Directorate for Information Operations and Reports, 1215 Jefferson Davis Highway, Suite 1204, Arlington

VA 22202-4302. Respondents should be aware that notwithstanding any other provision of law, no person shall be subject to a penalty for failing to comply with a collection of information if it

does not display a currently valid OMB control number.

\begin{tabular}{|c|c|c|}
\hline $\begin{array}{l}\text { 1. REPORT DATE } \\
\text { FEB } \mathbf{2 0 1 5}\end{array}$ & 2. REPORT TYPE & $\begin{array}{l}\text { 3. DATES COVERED } \\
\mathbf{0 0 - 0 0 - 2 0 1 5} \text { to 00-00-2015 }\end{array}$ \\
\hline \multirow{3}{*}{\multicolumn{2}{|c|}{$\begin{array}{l}\text { 4. TITLE AND SUBTITLE } \\
\text { Prospects for Iran's New Direction }\end{array}$}} & 5a. CONTRACT NUMBER \\
\hline & & 5b. GRANT NUMBER \\
\hline & & 5c. PROGRAM ELEMENT NUMBER \\
\hline \multirow{3}{*}{\multicolumn{2}{|c|}{ 6. AUTHOR(S) }} & 5d. PROJECT NUMBER \\
\hline & & 5e. TASK NUMBER \\
\hline & & 5f. WORK UNIT NUMBER \\
\hline \multicolumn{2}{|c|}{$\begin{array}{l}\text { 7. PERFORMING ORGANIZATION NAME(S) AND ADDRESS(ES) } \\
\text { U.S. Army War College,Strategic Studies Institute, } 47 \text { Ashburn } \\
\text { Drive,Carlisle,PA,17013-5010 }\end{array}$} & $\begin{array}{l}\text { 8. PERFORMING ORGANIZATION } \\
\text { REPORT NUMBER }\end{array}$ \\
\hline \multirow{2}{*}{\multicolumn{2}{|c|}{ 9. SPONSORING/MONITORING AGENCY NAME(S) AND ADDRESS(ES) }} & 10. SPONSOR/MONITOR'S ACRONYM(S) \\
\hline & & $\begin{array}{l}\text { 11. SPONSOR/MONITOR'S REPORT } \\
\text { NUMBER(S) }\end{array}$ \\
\hline
\end{tabular}

12. DISTRIBUTION/AVAILABILITY STATEMENT

Approved for public release; distribution unlimited

13. SUPPLEMENTARY NOTES

14. ABSTRACT

15. SUBJECT TERMS

16. SECURITY CLASSIFICATION OF:

\begin{tabular}{c|c|c|c|}
$\begin{array}{c}\text { a. REPORT } \\
\text { unclassified }\end{array}$ & $\begin{array}{c}\text { b. ABSTRACT } \\
\text { unclassified }\end{array}$ & $\begin{array}{c}\text { c. THIS PAGE } \\
\text { unclassified }\end{array}$ & $\begin{array}{c}\text { Same as } \\
\text { Report (SAR) }\end{array}$
\end{tabular}

\begin{tabular}{c|l}
$\begin{array}{c}\text { 18. NUMBER } \\
\text { OF PAGES } \\
\mathbf{5 9}\end{array}$ & 19a. NAME OF \\
& \\
&
\end{tabular}




\section{The United States Army War College}

The United States Army War College educates and develops leaders for service at the strategic level while advancing knowledge in the global application of Landpower.

The purpose of the United States Army War College is to produce graduates who are skilled critical thinkers and complex problem solvers. Concurrently, it is our duty to the U.S. Army to also act as a "think factory" for commanders and civilian leaders at the strategic level worldwide and routinely engage in discourse and debate concerning the role of ground forces in achieving national security objectives.
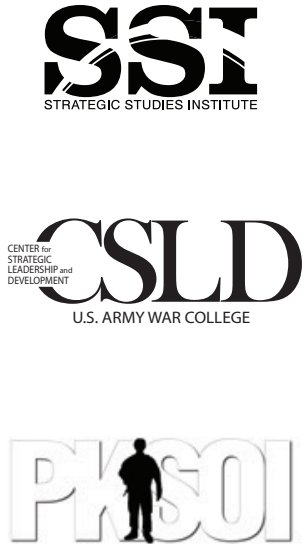

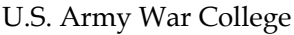

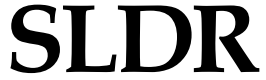

Senior Leader Development and Resiliency

The Strategic Studies Institute publishes national security and strategic research and analysis to influence policy debate and bridge the gap between military and academia.

The Center for Strategic Leadership and Development contributes to the education of world class senior leaders, develops expert knowledge, and provides solutions to strategic Army issues affecting the national security community.

The Peacekeeping and Stability Operations Institute provides subject matter expertise, technical review, and writing expertise to agencies that develop stability operations concepts and doctrines.

The Senior Leader Development and Resiliency program supports the United States Army War College's lines of effort to educate strategic leaders and provide well-being education and support by developing self-awareness through leader feedback and leader resiliency.

The School of Strategic Landpower develops strategic leaders by providing a strong foundation of wisdom grounded in mastery of the profession of arms, and by serving as a crucible for educating future leaders in the analysis, evaluation, and refinement of professional expertise in war, strategy, operations, national security, resource management, and responsible command.

The U.S. Army Heritage and Education Center acquires, conserves, and exhibits historical materials for use to support the U.S. Army, educate an international audience, and honor Soldiers-past and present. 


\section{STRATEGIC \\ STUDIES \\ INSTITUTE}

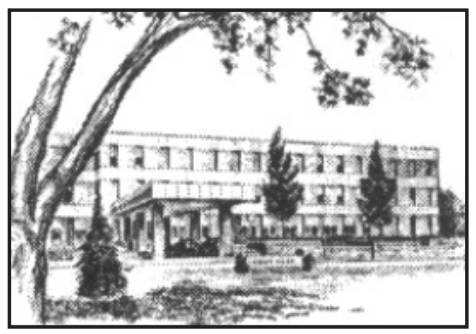

The Strategic Studies Institute (SSI) is part of the U.S. Army War College and is the strategic-level study agent for issues related to national security and military strategy with emphasis on geostrategic analysis.

The mission of SSI is to use independent analysis to conduct strategic studies that develop policy recommendations on:

- Strategy, planning, and policy for joint and combined employment of military forces;

- Regional strategic appraisals;

- The nature of land warfare;

- Matters affecting the Army's future;

- The concepts, philosophy, and theory of strategy; and,

- Other issues of importance to the leadership of the Army.

Studies produced by civilian and military analysts concern topics having strategic implications for the Army, the Department of Defense, and the larger national security community.

In addition to its studies, SSI publishes special reports on topics of special or immediate interest. These include edited proceedings of conferences and topically oriented roundtables, expanded trip reports, and quick-reaction responses to senior Army leaders.

The Institute provides a valuable analytical capability within the Army to address strategic and other issues in support of Army participation in national security policy formulation. 



\title{
Strategic Studies Institute \\ and \\ U.S. Army War College Press
}

\section{PROSPECTS FOR IRAN'S NEW DIRECTION}

\author{
Keir Giles
}

\section{February 2015}

The views expressed in this report are those of the author and do not necessarily reflect the official policy or position of the Department of the Army, the Department of Defense, or the U.S. Government. Authors of Strategic Studies Institute (SSI) and U.S. Army War College (USAWC) Press publications enjoy full academic freedom, provided they do not disclose classified information, jeopardize operations security, or misrepresent official U.S. policy. Such academic freedom empowers them to offer new and sometimes controversial perspectives in the interest of furthering debate on key issues. This report is cleared for public release; distribution is unlimited.

$* * * * *$

This publication is subject to Title 17, United States Code, Sections 101 and 105. It is in the public domain and may not be copyrighted. 
Comments pertaining to this report are invited and should be forwarded to: Director, Strategic Studies Institute and U.S. Army War College Press, U.S. Army War College, 47 Ashburn Drive, Carlisle, PA 17013-5010.

\section{$* * * * *$}

This manuscript was funded by the U.S. Army War College External Research Associates Program. Information on this program is available on our website, www.StrategicStudies Institute.army.mil, at the Opportunities tab.

$* * * * *$

All Strategic Studies Institute (SSI) and U.S. Army War College (USAWC) Press publications may be downloaded free of charge from the SSI website. Hard copies of this report may also be obtained free of charge while supplies last by placing an order on the SSI website. SSI publications may be quoted or reprinted in part or in full with permission and appropriate credit given to the U.S. Army Strategic Studies Institute and U.S. Army War College Press, U.S. Army War College, Carlisle, PA. Contact SSI by visiting our website at the following address: www.StrategicStudiesInstitute.army.mil.

$* * * * *$

The Strategic Studies Institute and U.S. Army War College Press publishes a monthly email newsletter to update the national security community on the research of our analysts, recent and forthcoming publications, and upcoming conferences sponsored by the Institute. Each newsletter also provides a strategic commentary by one of our research analysts. If you are interested in receiving this newsletter, please subscribe on the SSI website at www.StrategicStudiesInstitute.army.mil/newsletter.

ISBN 1-58487-669-7 


\section{FOREWORD}

In November 2014, tense negotiations over the status of Iran's nuclear program resulted in a 7-month extension of a compliance deadline. In June 2015, negotiators will once again be grappling with the same intractable issues, where neither Iran nor the United States and its allies appear able to make the substantive concessions that would be necessary for a permanent agreement.

This monograph, completed ahead of the November 2014 deadline, examines some of the underlying factors which will be constant in dealing with Iran under President Hassan Rouhani, and which will help determine the success or failure of talks in 2015. It surveys Rouhani's eventful first year in office in order to provide pointers to what may be possible - and to some key limiting factors - for Iran under his leadership. During that time, Rouhani was forced to balance his own progressive instincts with the instinctual caution of more conservative elements of the Iranian ruling elite. As a result, foreign hopes for his influence on Iran's place in the world have moved from initial optimism to a more sober assessment of the options available to him.

This monograph provides an essential backdrop to the forthcoming renewed negotiations by providing an introduction to the complex interplay of issues and interests which constrain the Iranian leadership. The Strategic Studies Institute recommends it not only to researchers and policymakers with an interest in Iran, but also, given Iran's central role in a number of cur- 
rent Middle Eastern security issues, to those working with the Middle East more broadly.

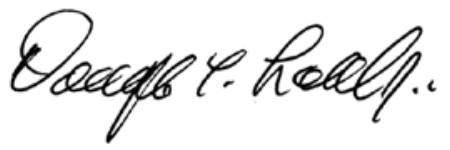

DOUGLAS C. LOVELACE, JR.

Director

Strategic Studies Institute and

U.S. Army War College Press 


\section{ABOUT THE AUTHOR}

KEIR GILES is the director of the Conflict Studies Research Centre (CSRC), a group of deep subject matter experts on Eurasian security formerly attached to the United Kingdom (UK) Ministry of Defence. Now operating in the private sector, CSRC provides in-depth analysis on a wide range of security issues. After beginning his career working with paramilitary aviation in Russia and Ukraine immediately following the fall of the Soviet Union, Mr. Giles joined the BBC Monitoring Service (BBCM) to report on political and military affairs for UK Government customers. While attached from BBCM to CSRC at the UK Defence Academy, he wrote and briefed for UK and North Atlantic Treaty Organization government agencies on a wide range of defense and security issues, focusing on the role of adversary human factors. Uniquely, he is a double Associate Fellow of the Royal Institute of International Affairs (Chatham House) in London, UK, as well as a regular contributor to research projects on security issues in both the UK and Europe. Mr. Giles's work has appeared in a wide range of academic and military publications across Europe and in the United States. 



\section{SUMMARY}

At the end of September 2014, Iranian President Hassan Rouhani made his second appearance at the United Nations General Assembly in New York. His previous visit, in September 2013, had seen the first telephone conversation between a U.S. President and an Iranian leader since 1979. Despite the domestic controversy it caused in Iran, the fact that this was possible was indicative of the significant changes in Iranian foreign policy that had already taken place since Rouhani's election as Iranian president, replacing Mahmoud Ahmadinejad.

President Barack Obama noted that, "I think this new president is not going to suddenly make it easy," ${ }^{1}$ but the prospects for a significant easing of tensions with Iran appeared good. Since his election, the new president had sent conciliatory messages to a range of Western governments, as well as to neighboring Arab Gulf countries, and in particular seemed willing to take a different approach on nuclear negotiations to that of Ahmadinejad. Nevertheless, President Obama still felt it necessary to specify that direct military action by the United States against Iran remained an option: "Iran should avoid thinking that the United States would not launch a military strike in response to Tehran's nuclear program just because it has not attacked Syria. ... They shouldn't draw a lesson that we ... won't strike Iran." ${ }^{2}$

One year later, Rouhani returned to New York under entirely different circumstances. The option of military strikes in response to Iran's nuclear ambitions had given way to stalemate over the extension of a groundbreaking agreement between Iran and the West that had seemed to promise a peaceful resolu- 
tion. Despite positive movement, the intervening year had clearly demonstrated the limited freedom of movement of the president in improving external relations - there was no prospect in 2014 of anything so daring as a telephone conversation with President Obama. ${ }^{3}$ A deadline for reaching further agreement on the status of Iran's nuclear program was close, and the consequences of failure to reach this agreement seemed alarming.

This monograph reviews the period since Rouhani's election in terms of these shifts in what seems possible and achievable for Iran, in order to draw conclusions about the likely future vectors for Iranian foreign policy. Although external relations regionally and internationally feature prominently on the agenda of the new Iranian leadership, they cannot be separated from Iran's domestic issues. Key junctures throughout Rouhani's first year of office emphasize that Iran is not a monolithic political body. The Iranian regime is constituted of a variety of political forces, and their influence on both nuclear negotiations and foreign policy more broadly is significant and pervasive. Any new approach adopted by an incoming Iranian President thus results from a shift in the thinking of other influential Iranian institutions, stemming from internal pressure. President Rouhani's initiatives enjoy the support of Supreme Leader Ayatollah Ali Khamenei, but this support is qualified and may have a limited duration.

\section{ENDNOTES}

1. Laura Rozen, “Obama Corresponds with Iran's Rouhani, Holds Out Hope for Nuclear Deal," Al-Monitor, September 15, 2013, available from backchannel.al-monitor.com/index. php/2013/09/6265/obama-says-exchanged-lettters-with-irans-rouhani/. 
2. "Obama Says Syria Deal Could Offer Lesson for Iran Talks," Reuters, September 15, 2014, available from www.reuters.com/article/2013/09/15/us-syria-crisis-usa-idUSBRE98D09C20130915.

3. "Rouhani: Time Not Right for Another Phone Call with Obama," The Times of Israel, September 27, 2014, available from www.timesofisrael.com/rouhani-time-not-right-for-another-phone-callwith-obama. 



\section{PROSPECTS FOR IRAN'S NEW DIRECTION}

\section{Introduction.}

At the end of September 2014, Iranian President Hassan Rouhani made his second appearance at the United Nations (UN) General Assembly in New York. His previous visit, in September 2013, had seen the first telephone conversation between a U.S. President and an Iranian leader since 1979. Despite the domestic controversy it caused in Iran, the fact that this was possible was indicative of the significant changes in Iranian foreign policy that had already taken place since Rouhani's election as Iranian president, replacing Mahmoud Ahmadinejad.

President Barack Obama noted that, "I think this new president is not going to suddenly make it easy $^{\prime \prime}$ - but the prospects for a significant easing of tensions with Iran appeared good. Since his election, the new president had sent conciliatory messages to a range of Western governments, as well as to neighboring Arab Gulf countries, and in particular seemed willing to take a different approach on nuclear negotiations to that of Ahmadinejad. Nevertheless, Obama still felt it necessary to specify that direct military action by the United States against Iran remained an option, he said:

Iran should avoid thinking that the United States would not launch a military strike in response to Tehran's nuclear program just because it has not attacked Syria. ... They shouldn't draw a lesson that we ... won't strike Iran. ${ }^{2}$

One year later, Rouhani returned to New York under entirely different circumstances. The option 
of military strikes in response to Iran's nuclear ambitions had given way to stalemate over the extension of a groundbreaking agreement between Iran and the West that had seemed to promise a peaceful resolution. Despite positive movement, the intervening year had clearly demonstrated the limited freedom of movement of the Iranian president in improving external relations - there was no prospect in 2014 of anything so daring as a telephone conversation with Obama. ${ }^{3}$ A deadline for reaching further agreement on the status of Iran's nuclear program was close, and the consequences of failure to reach this agreement seemed alarming.

This monograph reviews the period since Rouhani's election in terms of these shifts in what seems possible and achievable for Iran, in order to draw conclusions about the likely future vectors for Iranian foreign policy. Although external relations regionally and internationally feature prominently on the agenda of the new Iranian leadership, they cannot be separated from Iran's domestic issues. Key junctures throughout Rouhani's first year of office emphasize that Iran is not a monolithic political body. The Iranian regime is constituted of a variety of political forces, and their influence on both nuclear negotiations and foreign policy more broadly is significant and pervasive. Any new approach adopted by an incoming Iranian president thus results from a shift in the thinking of other influential Iranian institutions, stemming from internal pressure. Rouhani's initiatives enjoy the support of Supreme Leader Ayatollah Ali Khamenei, but this support is qualified and may have a limited duration. It follows that in order to assess the current prospects for maintaining Iran's trajectory toward cooperative engagement and compromise, we need to begin with the manner of Rouhani's arrival in office. 


\section{Retrospective: An Unexpected Victory.}

June 2013 marked an unexpected turn of events in Iranian politics, one that even some of the most optimistic commentators and analysts had failed to predict. Hassan Rouhani-a moderate and pragmatist cleric whose views on individual freedom, social issues and foreign policy diverged substantially from the ultra-conservative political establishment of the Islamic Republic - won a landslide victory in an election which many thought would be boycotted by the majority of Iranians supporting change and reform in the country's political system.

This result was highly significant, for a number of reasons:

- Rouhani was the only candidate representing pro-reform policies, against five conservative rivals.

- The election was held against the backdrop of the biggest political unrest the Islamic Republic had experienced since its victory in 1979. The Green Movement, which erupted across the country following the disputed 2009 presidential election resulting in Mahmoud Ahmadinejad's second term in office, had been suppressed by the regime, leaving the country divided and pro-reform voices in isolation.

- Opposition leaders Mir Hossein Mousavi and Mehdi Karroubi, the two reformist candidates of the 2009 election who led the subsequent street protests, had been placed under house arrest by the authorities since 2011 .

- Some members of the public who had taken part in the protests felt disillusioned with the 
political system, believing that the elite would rig any further election if they saw fit. Therefore, there were widespread calls for boycotting the election. Many opposition and pro-reform forces were of the belief that taking part in the election would be a betrayal of Mousavi and Karroubi and would only strengthen the ultraconservative establishment.

Nevertheless, nearly 37 million eligible Iranians voted in the election, an unexpected turnout of 72 percent. Rouhani, who had the backing of former presidents Akbar Hashemi-Rafsanjani and Mohammad Khatami, secured 51 percent of the votes, putting him well above the second candidate Mohammad Bagher Ghalibaf, the mayor of Tehran, with 16 percent. $^{4}$

During election rallies, Rouhani had promised his supporters to find a way to end international sanctions against the Iranian economy, which had halved its oil revenues, thus bringing the economy to its knees. This new direction in international relations for Iran was signaled without delay. In a press conference 3 days after his victory, Rouhani pledged to resolve confrontation over Iran's nuclear program through "constructive interaction" with the world. He said that Iran was ready to show "more transparency" on its nuclear activities, while still ruling out suspension of uranium enrichment procedures. Most Western powers "cautiously" welcomed the change of tone in the Iranian president's remarks, which were in direct contrast to Ahmadinejad's aggressive and often hostile rhetoric toward the West. ${ }^{5}$

Rouhani was sworn into office on August 4, 2013. In his first speech as president in the Iranian parliament, the Majlis, Rouhani urged the West to use the 
"language of respect," rather than sanctions, toward Iran. ${ }^{6}$ At the same time, he said that amending ties with regional neighbors would be his first priority in foreign policy, after relations with many Arab countries, prominently Saudi Arabia, had worsened under Ahmadinejad. $^{7}$

\section{Syria: The First Challenge.}

This ambition was immediately put to the test by the civil war in Syria. While Rouhani was still busy forming his cabinet and proposing his ministers to the Majlis, the United States and other Western powers accused President Bashar al-Assad's forces of having used chemical weapons, which had previously been defined as a "red line" by U.S. President Obama. ${ }^{8}$ The result was the highest likelihood to date of a U.S. strike on Syria.

As Iran's key ally in the region, Syria is instrumental in what Iran calls "the resistance front against the Zionist regime," ${ }^{\prime 9}$ primarily through support for the Lebanese Hezbollah. Therefore, Iran had defied global outrage against the Syrian government and President Bashar al-Assad since the beginning of the Syrian crisis, knowing that the departure of Assad would leave allies weaker and more vulnerable against Israel and the West.

\section{Iran and Israel.}

Iran has had no relations with "the Zionist regime," otherwise known as Israel, since the Islamic revolution in 1979. Israel is regarded as "an occupying regime" that has waged war on Muslims. The founder of the Islamic Republic of Iran, Ayatollah Ruhollah 
Khomeyni, referred to Israel as "a cancerous tumor"; and "liberation of Bayt al-Muqaddas," an Iranian term for Jerusalem, is considered one of the objectives of the Islamic revolution. ${ }^{10}$

Public remarks by former President Ahmadinejad in 2005, to the effect that Israel should be "wiped off the map," did little to improve the atmosphere. ${ }^{11}$ The two countries are prone to confrontational verbal exchanges, and the threat of Israeli air strikes on Iran's nuclear facilities became serious during Ahmadinejad's presidency.

Immediately after taking office, President Rouhani said that his administration would do all it could to prevent a possible U.S. strike on Syria. He acknowledged that chemical weapons had been used in Syria, but refused to blame government forces. ${ }^{12}$ The Iranian authorities - backed by some major powers such as Russia - maintained that it was the rebels, backed by Western powers, who had used these weapons, in order to provide a pretext for the United States to attack the Assad government.

This challenge, at the very start of Rouhani's presidency, provided an immediate confirmation of the continuing factionalism of Iranian politics, and the undiminished influence of hard-liners. While Supreme Leader Ayatollah Ali Khamenei confined himself to saying that the United States would "suffer loss" if it chose to attack Syria, ${ }^{13}$ some conservative elements within the establishment went as far as threatening that any U.S. strike against Syria would result in retaliatory attacks on Israel. Chief of Staff of the Iranian Armed Forces, Major-General Hassan Firouzabadi, stated that "any military measure against Syria will draw the Zionists deep into the fire [as well]."14 
If this threat had become reality, Israel, far more accessible than the United States, would have been Iran's main target. While unlikely to directly wage war on Israel, Iran could have used the militias of its proxies in the region, like Hezbollah and Hamas. With the undoubted influence of hardliners on Iranian action, despite presidential rhetoric, any strike on Syria could therefore have set the stage for full-scale hostilities in the region.

At the same time, while Russia's intervention in producing a plan for removal of chemical weapons from Syria prevented a potential war, Iranian influence also played a significant role in the eventual peaceful resolution. Iran exerted regional sway and maintained a stance which was more or less in line with that of Russia, making sure that in keeping with its strategic interest of saving its key ally Syria from war, it had backing from a significant partner like Russia if the United States went ahead with strikes. In Iranian and Russian perceptions, the combination of strong diplomatic maneuvering and the threat of action against Israel was successful in constraining the United States. Rouhani thus headed to New York for his first UN General Assembly session buoyed by the news that a potential disaster in his first year in office had been successfully averted.

\section{Breakthrough in Nuclear Talks.}

From the beginning of his presidency, Rouhani made it clear that finding a resolution to the nuclear standoff with the West and easing the sanctions on the Iranian people was his main focus in foreign policy. Although Iran under Ahmadinejad had attended a few rounds of talks with the European Union (EU), the 
two sides seemed to have reached a deadlock, with no short-term solution in sight.

This changed quickly under the new administration. Rouhani assigned the task of handling nuclear negotiations to the Foreign Ministry, thus putting Foreign Minister Mohammad Javad Zarif in charge. Before that, nuclear negotiations had been in the charge of Iran's Supreme National Security Council, a council headed by the president whose members are directly appointed by the Supreme Leader. Rouhani appeared to have taken this decision for two reasons: 1) He would have direct supervision on the progress of the nuclear talks; and 2) He trusted his personal friend, Zarif, to push Rouhani's agenda forward. Zarif, a veteran diplomat, had served in a range of posts in the Foreign Ministry. Educated in the United States, he had been Iran's permanent representative at the UN for several years and retained good connections with a large number of senior foreign diplomats.

It should be noted that despite this change, Supreme Leader Ayatollah Khamenei maintains the final say in all decisions regarding the nuclear program. It appeared that Rouhani had been given approval by Khamenei to move nuclear issues forward with a more open, transparent, and engaging agenda after 2 years of international sanctions had hit the Iranian economy hard.

Rouhani's nuclear maneuverings started as early as September 2013, on the sidelines of the UN General Assembly in New York. Zarif held a meeting with all the foreign ministers of the P5+1 (the five permanent members of the UN Security Council: the United States, the United Kingdom (UK), France, Russia, and China, plus Germany) and EU foreign policy chief Catherine Ashton. The meeting itself al- 
ready constituted an unprecedented breakthrough, as most major Western countries had refused to hold high-ranking meetings with Iranian officials during Ahmadinejad's presidency.

Zarif then held a bilateral meeting with U.S. Secretary of State John Kerry to discuss the nuclear issue, which made headlines the world over and represented a real change in Iranian foreign policy. This too was a first; with very few exceptions, direct negotiations with American officials had been a taboo in Iranian politics.

Iran and the $\mathrm{P} 5+1$ set out a platform in New York for further rounds of talks in the upcoming months. The two sides met in Geneva, Switzerland, in October the same year, but despite apparent progress, failed to agree on a deal. All the same, some Western diplomats attending the talks stated that they had seen "the most serious, intense" negotiations ever held with Iran. ${ }^{15}$

The response to these new developments within Iran confirmed the support for Rouhani's initiative from Ayatollah Khamenei. Opposition to the talks included hardliners opposed to Rouhani's "soft tone" on the West, who let it be known that they were "concerned" the government would offer significant concessions to the West for a deal. This was dismissed by Ayatollah Khamenei, who showed unequivocal backing for the talks: "No one should accuse our negotiating team of reconciling or compromising. These are our own children, the children of the revolution, who are doing a very difficult task." 16

Even with the backing of Khamenei, Rouhani had to ensure his negotiating team would not cross the Islamic Republic's immutable red lines. Khamenei, meanwhile, insured his position by making it clear that he was not optimistic about the outcome of the 
negotiations "because the Americans are not honest in talks and cannot be trusted."17 This would allow Khamenei the best of both worlds; if the talks failed to reach a resolution he would tell the nation that he was pessimistic from the very beginning, and if the two sides did agree to a deal, he could say that it was he who allowed the Rouhani administration to go all-out to secure it.

The real breakthrough, though, took place in November 2013 in Geneva. After marathon talks which included all the foreign ministers of the six world powers, Iran and the P $5+1$ agreed on a ground-breaking 6-month deal on November 24, which they named the "Joint Plan of Action."18 Iran agreed to curb some aspects of its nuclear program in return for relief from some sanctions. After the deal came into effect on January 20,2014, the two sides would then engage in further negotiations to find a comprehensive solution which would effectively resolve the decade-long standoff between Tehran and the West. July 20 was chosen as the deadline for agreeing to a comprehensive resolution. According to one assessment, the key factor in reaching the agreement was a decision by both sides to isolate nuclear negotiations from other contentious issues. ${ }^{19}$ This allowed progress without either side's negotiating position falling hostage to external considerations.

The impact of the agreement within Iran was entirely in keeping with its groundbreaking nature. The picture of Zarif shaking hands with Kerry after the deal had been agreed upon made the front page of the majority of Iranian papers the following day. The news was announced in Iran by the president himself, who hailed it as "a victory for the Iranian nation." Rouhani said that, as a result of the Geneva deal, the "archi- 
tecture of sanctions had cracked," and urged foreign investors to travel to Iran and use the opportunity to trade with Iranian businesses. ${ }^{20}$ On their return to Tehran, the negotiating team led by Zarif was mobbed by crowds celebrating the fact that their country had managed to strike a deal with the West. ${ }^{21}$

Predictably enough, however, while it seemed that the Joint Plan of Action deal had the backing of the majority of Iranians, it made the hardline and ultraconservative campaigners more vocal in their criticism. They believed that Iran had given up too much for too little, some of them going as far as to say that Rouhani and the negotiating team had "betrayed our nuclear martyrs" - a reference to the assassinations of a number of Iranian nuclear scientists, for which Iran holds Israel responsible. ${ }^{22}$

\section{Restarting Regional Relations.}

President Rouhani's next foreign policy target following the nuclear deal in Geneva was active diplomacy in Iran's immediate neighborhood. Some Arab states had expressed their concern about Iran's nuclear program in the past, specifically under Ahmadinejad's hardline administration. Now, with an interim deal in hand, Rouhani could start rebuilding relations with regional states. Zarif began an intensive round of diplomatic visits. He visited Kuwait and Oman, and met his counterparts from Turkey and the United Arab Emirates (UAE) in Tehran. Zarif even expressed willingness to make a visit to Saudi Arabia. ${ }^{23}$

Iran had offered unconditional support to President Bashar al-Assad since the beginning of the civil war in Syria in 2011. The issue was an obstacle to relations with several countries in the region. Now, 
although the Syrian crisis was still at the heart of Tehran's diplomatic efforts, Iran also hoped that rectifying its disturbed relations with regional states would pave the way for reaching a lasting agreement with the West on the nuclear issue-bearing in mind that several Gulf states, especially Saudi Arabia, are perceived as key U.S. allies in the region.

Talks with Turkey were held in attempts to address the Syria issue. Turkish Foreign Minister Ahmet Davutoglu travelled to Tehran to attend the 21st meeting of the Council of Ministers of the Economic Cooperation Organization (ECO) in November 2013, and held a joint press conference with his Iranian counterpart, Zarif, which reported progress. "We have shared stances on many issues and also some differences on the crisis in Syria and we hope that we can resolve these differences with the help of each other," Zarif said. ${ }^{24}$ Davutoglu further announced that Rouhani would visit Turkey in January 2014.

With Arab states in the region, the main focus besides direct bilateral relations was to address concerns about Iran's nuclear program. UAE Foreign Minister Shaykh Abdallah Bin-Zayid Al Nuhayyan arrived in Tehran on November 28 on a rare official 1-day visit. The two countries have had a long dispute over a number of bilateral issues, including sovereignty over three islands in the Persian Gulf. In his meeting with Zarif, Al Nuhayyan and his Iranian counterpart called for opening a new chapter in bilateral ties. Zarif followed up with a visit to Kuwait and Oman. Relations between Iran and Kuwait had been strained for the previous 3 years, after accusations of Iranian espionage activities in Kuwait. Meanwhile, the Omani Sultan was the first foreign head of state to visit Tehran after Rouhani took office. Oman was 
reportedly instrumental in making possible Iran's nuclear deal with the P5+1, thanks to months of secret talks between U.S. and Iranian officials in the Omani capital, Muscat. ${ }^{25}$

Iran and Saudi Arabia have been rivals over past decades, both aspiring to be the major power in the Persian Gulf. In addition to Iran's disputed nuclear programs, the two oil-rich states were at loggerheads over influence in some other countries including Iraq, Bahrain, and Syria. Saudis consider Iran-U.S. rapprochement as a risk which might disturb the balance of power in the region in favor of Iran. ${ }^{26}$ As a consequence, Saudi Arabia had expressed concerns about the nuclear talks in Geneva. Despite these concerns, Saudi Arabia cautiously welcomed the deal with the $\mathrm{P} 5+1$, calling it "a first step towards a solution if there are good intentions." ${ }^{27}$

Rouhani had indicated in his first press conference after the June elections that amending ties with Saudi Arabia would be a priority for the new government. This reflects the fact that better relations with regional states would facilitate striking a long-term deal with the West. According to a front-page article in the reformist Sharq daily in November 2013:

If instead of disturbing our diplomatic ties with the influential countries in the region and world such as Saudi Arabia, France and Britain we had made efforts to minimize the number of our obstinate enemies, we would not have reached a point where our numberone enemy [the U.S.] would be ready for a deal but other states overturn the table. ${ }^{28}$

Iran is also cognizant of Saudi influence both in the region, such as through the Gulf Cooperation Council (GCC), and in broader international organizations, 
such as the Organization of Islamic Cooperation (OIC) and the Arab League. Potentially, reaching an agreement with Saudi Arabia over a number of disputed regional issues could help both sides to maintain their position in the region. A visit by Zarif, or by former President Akbar Hashemi-Rafsanjani, known to have good relations with Saudi leaders, would explore channels toward that goal and pave the way for a possible detente.

\section{Thaw with the UK.}

One of the major changes under Rouhani was resumption of ties between Tehran and the UK after relations between the two countries had been at their lowest level for some considerable time on Rouhani's entry into office. Resuming diplomatic ties with the UK would be considered significant in Tehran due to Britain's perceived status as the closest U.S. ally in Europe, with the potential to act as a bridge between Tehran and Washington for further developments in relations. In addition, as a member of the P5+1 group, the UK was essential to any possible nuclear deal.

In December 2011, the British government had announced that it was imposing unilateral sanctions on the Iranian Central Bank. The decision came at the height of international sanctions on Iran, where Iranian banks and businesses were directly targeted by the West. In retaliation, the Majlis passed a bill that restricted relations with Britain to the level of chargé d'affaires. A few days later, a group of hardline students ransacked the British Embassy and another UK diplomatic facility in Tehran, chanting "death to Britain." Despite occasional animosity between the two countries and regular demonstrations, this was the 
first time the embassy had been actually overrun since 1979. ${ }^{29}$ In response, UK Foreign Secretary William Hague closed the embassy, and asked Iranian diplomats in London to return home, a move seconded by Canada.

Even after these events, Hassan Rouhani was well placed to rebuild ties; Rouhani had lived in Britain, and acquired his doctorate from Glasgow Caledonian University in Scotland. Among his congratulatory messages on winning the presidential election was one from UK Prime Minister David Cameron, hoping that ties with Iran would improve on "a step by step" basis.

Foreign Ministers Zarif and Hague met on the sidelines of the UN General Assembly session in New York in September 2013, and agreed to work toward restoration of diplomatic ties. In October, the two countries agreed to appoint nonresident chargés d'affaires, Mohammad Hassan Habibollahzadeh and Ajay Sharma, who would work toward the reopening of embassies and full restoration of ties. ${ }^{30}$ Habibollahzadeh and Sharma met several times in Tehran and London, both noting that the process was proceeding positively. Finally, in February 2014, the Iranian embassy building in Kensington, London, reopened and began offering limited services to Iranian nationals living in Britain. The British embassy in Tehran remains closed to date, which may reflect the intention of the British government to await the result of current nuclear negotiations. A renewed nuclear deal would likely pave the way for full restoration of diplomatic ties between the two nations. In this atmosphere, a meeting in September 2014 between Rouhani and UK Prime Minister David Cameron on the fringes of the UN General Assembly, while progressive, was brave 
considering the deep suspicion with which the UK is regarded in Tehran. ${ }^{31}$

\section{Ties with the United States, Phone Call with Obama.}

The first sign of change in Iran's bilateral relations with the United States came as early as July 2013; in a press conference, the new president said that Iran and the United States could not remain enemies forever, and that any thaw in relations would depend on the way the United States interacted with Iran. Meanwhile, Obama said that he "cautiously" welcomed the arrival of the new Iranian president, stressing that doors would be open for Iran if it was serious in taking on a new approach in relation to its nuclear program. ${ }^{32}$

This cautious beginning was entirely overshadowed almost 2 months later during Rouhani's visit to New York for his first UN General Assembly speech. Rumors of a possible meeting between Rouhani and Obama had been circulating in the media. This would have been a true breakthrough, as no Iranian president had ever dared even to contemplate aloud a face-to-face meeting with his counterpart from "the great Satan," the root of all evil. Naturally enough, any direct interaction with Satan would have been anathema to the Islamic Republic.

Nonetheless, in the early hours of the final day of Rouhani's visit to New York, a Twitter account belonging to Rouhani announced in English that he and Obama had spoken over the phone. This marked the first such conversation between an Iranian and American leader since the Shah's departure and the subsequent toppling of the Pahlavi dynasty in 1979. The phone conversation, and the succession of chummy 
tweets between the two leaders that followed as Rouhani departed for the airport, was hailed as "historic" by world media, and taken as denoting a serious intent by Rouhani to fix the long broken ties with the world's greatest power.

The news also caused enthusiasm and excitement in Iran, but this was followed swiftly by concern. Only a few hours later, the tweets which included details of the phone conversation between Obama and Rouhani were deleted without explanation. It was suspected that Rouhani had encountered a significant backlash from the ultra-conservative elements in the establishment, who considered a major red line had been crossed by the president. ${ }^{33}$ Speculation on whether Ayatollah Khamenei had authorized the conversation ended when Khamenei stated that despite his support for the government's active diplomacy, "some of the things that happened in New York were not right." ${ }^{34}$

The ground-breaking Geneva deal, which was achieved after direct talks between Iranian and U.S. negotiators, had raised hopes about the possibility of the two sides widening talks into bilateral relations. But once again, the Supreme Leader stressed that the negotiating team was only allowed to talk to American representatives about the nuclear issue, and no other topic was on the table. As a consequence, there has been little progress in bilateral ties since the historic phone call and the Geneva deal, despite regular meetings between the two countries' negotiators as part of the ongoing nuclear talks.

Iran still accuses the United States of supporting Israel and creating unrest in the region to serve its own purposes. The majority of Iranian political figures have repeatedly hinted that any failure to reach a comprehensive deal on the nuclear program should 
be blamed on the United States, because, they claim, Washington is derailing the talks with "unreasonable demands." Despite media rumors of the possibility of Tehran and Washington working together to counter the threat posed by the Islamic State in the region, Iran has said that it does not need to cooperate with the United States and would rather work with its regional allies to fight the Islamic State. Nevertheless, Rouhani's 2014 UN General Assembly speech appeared to offer a specific invitation for cooperation against the Islamic State, conditional on progress in nuclear negotiations. He said:

If our interlocutors are motivated and flexible, we can reach a longstanding agreement within the time remaining. Then an entirely different environment will emerge for cooperation at regional and international levels, for example in combating violence and extremism in the region. ${ }^{35}$

Seyed Hossein Mousavian, former head of the Foreign Relations Committee of the Iranian Supreme National Security Council, suggests that without active Iranian support, no major peace effort in the Middle East can succeed-with particular reference to support for the U.S.-led coalition against the Islamic State. His suggestion for achieving this, as well as detailed recommendations for a roadmap for nuclear negotiations, is engagement with Iran, recognizing and accepting the extent of Iranian power and influence in the region. ${ }^{36}$

\section{Iran and the Islamic State.}

Iran has made it obvious that it takes the threat of the Islamic State very seriously, although at the same 
time shrugging off any concern about being targeted by Islamic State militants. Iran has suggested that the best way to counter the Islamic State is to leave it to the governments in Iraq and Syria. This reflects a suspicion of any foreign intervention, based on awareness of the possible risks to Iranian ally Assad. Despite this declaratory policy, photographs of General Ghasem Soleimani of the Islamic Revolutionary Guards Corps (IRGC) have been circulated via social media showing him alongside Shia Iraqi fighters combating the Islamic State. Whether he has put together his own force to fight the Islamic State, or he is merely providing assistance is unspecified in open sources, but this would reflect the unlikelihood of Iran actually being willing to leave constraint of the Islamic State to Iraq and Syria's own efforts as claimed, which would inevitably allow the Islamic State to subdue still more territory. ${ }^{37}$ A possible trip by Zarif or even Rouhani himself to Saudi Arabia, which is appearing increasingly likely, would present an opportunity to discuss ways to fight the Islamic State, or come to an agreement on the possibility of Tehran taking part in some form of a coalition against the Islamic State, with or without the United States.

\section{Outlook: Relations with Saudi Arabia and Turkey.}

Iran will necessarily be a key player in any eventual resolution of the Syrian conflict, whether political or military, notwithstanding its exclusion from the Geneva 2 conference in January 2014. Any political resolution of this kind would entail Iran reaching an understanding with other key regional players, particularly Saudi Arabia and Turkey. Statements on the Syria issue by Iranian officials have been very consis- 
tent, and can be read as indicating that Iran sees no need at present to offer any substantial concessions or deviations from its declared support for the Assad government. Thus, there is a potential conflict between Rouhani's policy of regional engagement and rapprochement, and the tougher stance of the military establishment which stresses defending Iran's strategic interests.

The official government position has been repeatedly articulated by Zarif. He has stressed the need for a political solution, to be determined by the Syrian people after the withdrawal of what he has termed "all foreign forces." 38 Iran would be prepared to use its influence with Damascus to bring about a ceasefire and the withdrawal of foreign fighters, Zarif added, if others used their influence on other combatants with the same goal. At the same time, he echoed Russian warnings of the rise of "extremism" in Syria, describing it as "a regional and global menace." ${ }^{39}$

This specter of an increase in the global terrorism threat is also used by Iranian military sources, although more forcibly and with a different emphasis. This military viewpoint is frequently voiced by Major General Yahya Rahim-Safavi, former head of the IRGC and now military adviser to Ayatollah Khamenei. In February 2014, Rahim-Safavi said that the extremist "takfiri" groups operating in Syria had been "masterminded by the United States while financially supported by the Zionist regime and certain Arab states." 40 Previously, he had warned that some Arab kingdoms could disappear by the year 2030. ${ }^{41}$

Any decision to improve ties with Saudi Arabia in particular would need to be taken by the Supreme Leader himself, with input from military as well as government and diplomatic figures. This would 
account for the fact that no official ministerial visit has yet taken place, despite statements of readiness. A recent Saudi decree criminalizing citizens going to fight in foreign countries, and those encouraging them, could be seen as a first step toward creating a favorable environment for talks with Iran. It could also be seen as a tacit acknowledgement that the emphasis on the threat from terrorism stated by Iran, Syria, and Russia is currently winning the argument.

Iran's relations with Turkey are much warmer than those with Saudi Arabia. But a visit to Tehran of a Turkish delegation headed by the then prime minister Recip Tayyip Erdogan showed that there are still differences to overcome. A speech Erdogan was due to give at the Iranian Foreign Ministry was cancelled, reportedly because his meeting with Rouhani took longer than scheduled. ${ }^{42}$ Iranian First Vice-President Eshaq Jahangiri said at a news conference that agreement had been reached on a natural gas deal. But Turkish Energy Minister Taner Yildiz then told reporters that there had been a mistranslation, and there had merely been talks about the deal. Furthermore, Iranian interest in a resolution in Syria needs to be placed in context; Syria is subsidiary to the nuclear issue as Iran's top foreign policy concern. Any efforts to pave the way for a negotiated solution to the Syria issue run the risk of falling hostage to the progress of the nuclear talks. Meanwhile, Iranians feature heavily among the "foreign forces" active in Syria. 


\section{The Extent of Iran's Military Involvement in Syria.}

On May 27, 2014, Iranian website Rajanews carried a very brief report, saying that a commander in the IRGC, Abdollah Eskandari, had been "martyred" in Syria. Eskandari's death attracted little media attention. A commemoration ceremony in his home province of Fars on June 1 was the subject of a 2-minute report on the local television channel. The ceremony, and a message of condolence from the country's defense minister, was also reported by the Islamic Republic News Agency (IRNA) and Mehr news agencies. ${ }^{43}$

The official Iranian line is that it has no combat presence on the ground in Syria, although it acknowledges providing military advice and assistance, and that Iranians have gone there to fight as volunteers. But following Eskandari's death, a report in the Gulf quoted Syrian opposition sources as saying that he was the 60th Iranian "officer" to have been killed in Syria. ${ }^{44}$ Iranian media sources have only reported the deaths of 21 fighters in Syria since the beginning of 2013. This reporting mostly takes the form of announcement of their funerals once the bodies have been repatriated, which is usually done within 2 to 3 days of their deaths. Neither of these figures is substantial, in the context of the death toll in Syria's civil war, which is now put at over 150,000. Analysts estimate that approximately one-third of those casualties have been incurred by forces fighting on the government side, whether regular or irregular.

Although there are variations in the exact terminology used, Iranians killed in Syria are almost always described as defenders of the Shia shrines in Damascus, principally the shrine of Sayyidah Zaynab in the 
southern suburbs, but also that of Sayyidah Ruqayya on the edge of the Old City. ${ }^{45}$ The term "defenders of the shrine" is generic, and should not be taken as an indication of geographic location of their deaths. In most cases there are few details of the circumstances in which they were killed. The fighters are also referred to as volunteers, but a study of the published obituaries and eulogies, along with the photographs that accompany them, shows that they almost all have clear military connections.

While the Iranian authorities seem to impose no restriction on the reporting of the deaths of Iranians in Syria, they do seem sensitive to wider discussions or revelations about the extent of Iran's role in the conflict. On a number of occasions, news agencies have withdrawn or modified reports related to the war. In May 2014, Fars published a report in which a former IRGC commander, Brigadier General Hoseyn Hamedani, spoke of Iranian support for Syria, saying that "Iran has established a second Hezbollah in Syria," and "some 130,000 Basij volunteers have been trained and are waiting to enter Syria." Twenty-four hours later the report had been removed from the website.

Earlier, in February, Fars removed a paragraph from remarks by Member of Parliament (MP) Mahmud Nabavian after they had been widely quoted by other Iranian media outlets. Nabavian said, in the redacted remarks: "We brought 150,000 Syrians to Iran and provided them with military training. We trained 150,000 over there and also sent 50,000 Hezbollah forces there." Subsequently, Majlis Speaker Ali Larijani told a closed session of parliament that MPs should "exercise more caution" in their statements and "observe security concerns." ${ }^{46}$ It is worth pointing out that the numbers quoted by Nabavian may be exaggerated. 
Western analysts estimate that Hezbollah has had no more than about 5,000 troops in Syria at any one time, while the strength of the Syrian paramilitary forces trained by Iran is thought to be around 100,000.

Another instance occurred when the Anarma website, based in Kerman Province, quoted an IRGC commander as telling a local memorial ceremony in March 2014: "Everybody saw when Commander Soleimani entered Syria; the enemy [the United States] paid attention and did not talk about a military invasion against Syria anymore." Ghasem Soleimani, as the commander of the IRGC's Quds Force, is responsible for external and special operations, and has been described by opposition groups as the "de facto ruler" in Damascus. Two days later, the website posted an edited version of the report with the reference to Soleimani removed. ${ }^{47}$ Despite this apparent sensitivity over the mention of Soleimani, he has been shown a number of times in photographs attending the funerals of some of those killed in Syria or consoling their families.

Iran may also be using Syria as a testing ground for new technology. In September 2013, the Iranian military unveiled a range of new, domestically-produced unmanned aerial vehicles (UAVs), which were shown in reports on state television. First was the IRGC's combat-capable Shahed 129. The next day, the regular ground forces displayed three models, including the Yasir, thought to be based on a U.S. drone which Iran said it had captured in December 2012. As early as November 2013, Syrian activists were posting videos to YouTube which appeared to show a Yasir being flown over Damascus. ${ }^{48}$ And in December, the Al-Qaida-affiliated Al-Nusrah Front provided Al-Jazeera TV with video footage of a Yasir it claimed to have shot down over Aleppo. ${ }^{49}$ 


\section{Outlook: Prospects for Nuclear Talks.}

Despite a visit to Iran by Director-general of the International Atomic Energy Agency (IAEA) Yukiya Amano in August 2014 being described by the Iranian Foreign Ministry as "constructive," it is not clear whether Iran and the West will be able to resolve the standoff between the two sides over Tehran's nuclear program..$^{50}$ While there exists a degree of optimism in Rouhani's moderate administration and the reformist media, most of the Iranian authorities, including Supreme Leader Khamenei, and the majority of the country's prominent media outlets, have been highlighting "serious differences" that cast a shadow over the prospects for a comprehensive agreement. Khamenei has repeatedly gone on record to declare his pessimism about the outcome of the negotiations, while maintaining his support for the negotiating team led by Zarif. Media outlets have echoed Khamenei, and broad domestic support for a settlement is far from guaranteed.

The Geneva deal raised hopes of the possibility of a comprehensive agreement, but the more detailed negotiations proved more challenging, with the two sides failing to reach an accord by the July 20 deadline despite holding six rounds of marathon talks. As a result, the deal was extended by a further 4 months, to November 24, 2014- by which date a compromise must be found. As part of the Geneva deal, Iran had agreed to provide detailed information to the IAEA about its nuclear program, with the agency then responding with questions. Although Iran says it has answered all the questions transparently, some highranking officials have expressed frustration about some of the agency's new requests. 
Following a meeting with Yukiya Amano in Tehran on August 17, 2014, Ali Akbar Salehi, the director of the Atomic Energy Organization of Iran, said that Iran had voiced its concern about the issue of exploding-bridgewire detonators (EBW), a crucial component for a nuclear weapons program. "There used to be no more than two or three questions about EBW, but they suddenly rose to 60 questions and we complained about this," Salehi said. ${ }^{51}$ Reza Najafi, Iran's permanent representative at the IAEA, echoed Salehi's remarks, criticizing the IAEA for making "some illogical demands." 52

Opponents of the agreement took the opportunity to voice pessimism over the negotiations. According to conservative daily Hemayat:

With the arrival of Yukiya Amano in Tehran, there is a serious question as to whether a new nuclear agreement with the agency is on the way. . . . Iran has successfully come to trust the IAEA, and now it is the IAEA's turn to adopt measures to create trust towards Iran. This is because creating trust is a two-sided game. If it cannot convince Iran to have cooperation, it should not expect more cooperation from Iran. ${ }^{53}$

Previously, in May 2014, influential hardline daily Keyhan had called it "indubitable" that the negotiations would "never have the desired conclusion" for the Islamic Republic.

Iran has also accused Western powers of making "excessive demands," which it says have made the negotiations more complex. Iran is particularly concerned about any questions with regard to its defense and missile capabilities, defining such issues as its "red lines" in the talks. "Negotiations on lifting the sanctions have led to no specific results," Khamenei said at a meeting with Iranian ambassadors and diplomats 
on August 13, 2014. Two days later, Iranian state TV aired a 20-minute report about the prospects for the talks, claiming that the two sides had failed to meet the July deadline due to these "excessive demands" by the West, specifically the United States:

As stated so many times by our officials, resolving Iran's nuclear program is not a complex issue, as long as the U.S. recognizes Iran's rights and, with its excessive demands, does not push the negotiations towards failure once again.

Finally, on August 18, Zarif said that Iran would not agree to a deal unless the P5+1 lifted all the sanctions on Tehran, something U.S. officials strongly oppose. ${ }^{54}$ Defiant messages also came from Majid TakhtRavanchi, a deputy foreign minister and a member of the negotiating team, who called on Western powers to drop "illusions":

We have done all we could to resolve the nuclear issue, and this is clear to the people of Iran and the public opinion in the world, but we are not willing to reach an agreement at any cost. Our flexibility has limits and we will negotiate based on the framework that has been agreed. ${ }^{55}$

Despite the remaining differences, Iran and the P5+1 were scheduled to start a new round of talks on the sidelines of the UN General Assembly session in September 2014.

\section{Prospects for Agreement....}

Any comprehensive agreement by November 2014 would require significant concessions by both sides. At the time of this writing, neither side is showing 
willingness to reconsider its stance. Complete suspension of enrichment activities would be a politically unviable move for Iran. This is because of the amount of time and funds spent on the nuclear program to date, and, more importantly, the heavy price paid by the Iranian people for the program: enduring severe sanctions, negative economic growth for 2 consecutive years and an unprecedented surge in inflation. Even a significant scaling back of enrichment plans would draw intense criticism not only from officials and commentators, but also from ordinary people. Although independent poll information to gauge the views of the public on matters concerning national security does not exist in Iran, anecdotal evidence and reporting suggest that the majority of Iranians, including many on the reformist camp, are strongly in favor of the nuclear program. Any major concession by the government would leave it in a fragile and shaky position, and the subject of outrage.

The transparency demanded by the international community is in some respects problematic. Iran has repeatedly said that it is willing to provide more transparency, but is deeply concerned about increasing its vulnerability to possible military action by Israel or the United States by giving away too many details of its nuclear facilities. Besides the dubious prospect of a comprehensive deal, another possible outcome could be a further extension of talks. But this would risk favoring critics of Rouhani, who have consistently argued that the government is wasting time and money on something which could never result in a desirable outcome for the country. Some influential MPs have warned that failure in talks would lead to Iran expanding its nuclear activities, and putting together a plan for enriching uranium to 60 percent. That could 
have grave consequences for both Iran and the West, as it might push Israel further toward air strikes on the nuclear facilities. ${ }^{56}$ At the time of this writing, it appeared that both sides were preparing for the probable consequences of a no-deal scenario, despite efforts to keep a positive tone about the prospects for agreement.

\section{... and Remaining Differences.}

Major differences between the two sides were exposed during the more detailed negotiations which followed the Joint Plan of Action. The level and volume of Iran's enrichment program, the future of its heavy water reactor in Arak, its research and development program, and finally the lifting of sanctions were key areas of disagreement.

The number of Iran's centrifuges is a major stumbling block in the talks. The West wishes Iran to reduce its stock of centrifuges to numbers in the thousands, while Iran demands numbers in the tens of thousands. At the time of this writing, Iran had more than 19,000 installed enrichment centrifuges at its nuclear facilities, while continuing to maintain that it has the right to enrich uranium for peaceful purposes and to deny that the intention is to develop a nuclear weapon.

The major powers are also opposed to the installation of a new generation of centrifuges at Iran's underground Natanz and Fordo enrichment plants. Iran, however, argues that it has the right to pursue nuclear research and development.

Iran's suspected weapons research activities pose another challenge. Iran has offered to implement the Additional Protocol to the Nuclear Non-Proliferation Treaty (NPT) if sanctions against it are lifted. The 
Additional Protocol requires IAEA member states to provide an expanded declaration of their nuclear activities and grant the watchdog more access to their nuclear sites. Meanwhile, the West is already requesting stricter international inspection and is not satisfied with progress after Iranian agreement to cooperate with the IAEA.

Another obstacle is Iran's Arak heavy-water research reactor. The $\mathrm{P} 5+1$ is concerned that the project, once operational, could produce plutonium. Iran maintains that Arak produces radio isotopes purely for civilian purposes such as agriculture and medicine. Some Iranian officials have said they are already trying to redesign the reactor to cut its potential output and alleviate international concerns. In return, Iran is demanding the swift lifting of sanctions imposed on the country over the past 8 years. The additional sanctions on Iranian oil exports and banks imposed by the United States and the EU since 2012 have been particularly damaging to the Iranian economy. However, coming up with a comprehensive plan to lift all sanctions will be a major challenge for the West, especially given the ability of the U.S. Congress to block their removal. The United States in particular faces a major test in working out how to appease Israel in the event of any outcome that could help Tehran maintain its nuclear enrichment activities. For these reasons among others, pessimists in Iran are concerned that it may take years, even decades, for the sanctions to be lifted in their entirety.

\section{What Would a Comprehensive Deal Mean?}

A comprehensive agreement over Iran's nuclear program could draw to a close a regional challenge that has exercised the United States and the West 
over the past 2 decades. A final deal could help both Iran and the West to normalize ties and cooperate on various regional issues. This could include working together on some of the adverse developments rapidly unfolding in the Middle East, including but not limited to the emergence of the Islamic State in Iraq.

But an agreement which allowed Iran to continue any form of nuclear development would be unsatisfactory for the Middle East's only nuclear power, Israel, which is demanding a total dismantling of Iran's nuclear program. Some Arab states, including Saudi Arabia, are also deeply concerned about any Iranian nuclear activity. A final agreement would be a significant boost for Rouhani's attempts to tackle serious economic problems. The lifting of sanctions that would follow would allow Iran to rebuild its seriously damaged economy, which in turn would favor Rouhani's own popularity.

A nuclear deal might not bring about radical social or political change in Iran, but it could at least pave the way for a beginning of reform in domestic politics. Hardliners, as major opponents of Rouhani's administration and the nuclear deal, could potentially be further sidelined, and replaced by Rouhani's camp of reformists and moderate conservatives. Furthermore, since Ayatollah Khamenei has hedged his bets over the outcome of the talks, any possible agreement would inevitably be portrayed as a success for him. Despite strong criticism by ultra-conservatives, Iran's negotiating team has so far enjoyed Khamenei's support. But it is not clear how long this support will last. Khamenei disapproved of the detente policy pursued during the 1997-2005 presidency of the reformist Mohammad Khatami, arguing that it only "emboldened" the West, particularly over the nuclear dispute. Hardliners are now already leveling the same charge at Rouhani. 


\section{Risks of Failure.}

Concern over the patience of conservative elements running out may already have been at the front of Rouhani's mind when he warned in September 2013 that the opportunity to reach an agreement over Iran's nuclear program is not "unlimited." 57 A total failure in the nuclear negotiations would have serious implications for all parties. Both sides in the talks have already announced what could happen if the talks are unsuccessful. "International sanctions will tighten and Iran's isolation will deepen," warned U.S. Secretary of State John Kerry in a Washington Post op-ed on June 30, 2014. ${ }^{58}$ Senior Iranian diplomats, such as Deputy Foreign Minister Abbas Araqchi, warned in return that if the talks fail, Iran would resume production of 20 percent-enriched uranium, which was suspended as part of the interim deal. ${ }^{59}$

Failure would also pose an immediate threat to Rouhani's administration at home, and thus to the active engagement with the region and the world by Iran that has been Rouhani's policy since he took office in August 2013. The end of this incipient detente could lead to a return to the confrontational style of Rouhani's predecessor, Mahmud Ahmadinejad.

Rouhani has been banking on a deal as a tool which could transform the economy, allowing in foreign investors and lifting sanctions on Iranian banks. Failure in the talks would thus not only be a foreign policy failure and a blow to his moderate/reformist agenda, but also a severe setback for Iran's economy regardless of who is in power.

But ultra-conservative critics have already attacked Rouhani for linking the country's economic issues to the removal of sanctions. Instead of trying to lift the 
sanctions, hardliners have called for implementation of the "Resistance Economy." ${ }^{60}$ The term denotes measures outlined by the Supreme Leader aimed at modifying the economy to reduce its vulnerability to sanctions. Once again, in the event of failure, Rouhani's position would be undermined and the advocates of the Resistance Economy would be reinforced.

In effect, to the extent that Rouhani's supporters and the Iranian public as a whole are putting their trust in Rouhani to deliver a deal with the West and thus resolve Iran's economic crisis, there is a realistic prospect of a continued trajectory toward reform and engagement. Conversely, that trust will not last indefinitely; a failure by Rouhani, and consequent continued economic trauma, could lead Iran down a regressive and potentially unpredictable and dangerous path.

\section{Outlook and Policy Implications.}

The United States and Iran do have common security interests, especially at the present time. The fight against terrorism, stability in Afghanistan, and peace in Iraq are all prime Iranian concerns. But for the time being, the nuclear problem appears once again to provide a block to effective engagement on shared concerns as well as to progress in all other foreign policy issues. At present, therefore, all hinges on the progress or lack of it of nuclear talks.

In the Iranian domestic debate, the nuclear program is an intensely politicized issue. It feeds off antagonism between Iran and the United States, which in turn exacerbates the political importance of nuclear development still further. If either one of these two factors were removed, the vicious cycle would collapse, 
and the prospect of enhanced cooperation between the United States and Iran for the sake of regional security would open. But this would require a strategic shift on both sides.

Given U.S. demands that Iran reduce its capacity to enrich uranium - and keep it reduced for a period of decades - the concessions required on either side to reach an agreement would be difficult and painful, and at the time of writing, neither side appeared willing to rise to the challenge. Indeed, both sides are prevented by domestic circumstances from reaching agreement. Iran needs to present any agreement as a victory to its domestic audience. There cannot be any appearance of significant concessions. The United States, too, cannot appear to back down not only because of its strategic position, or the effect on relations with key allies in the region, but also because of Israeli influence on U.S. foreign policy and the requirement for a deal to pass through Congress, famously described as " 535 U.S. Secretaries of State, each with their own views."

Recent developments appear to favor both sides equally. The dramatically improved domestic U.S. oil production makes it easier to place sanctions on Iranian oil exports with a much reduced risk of intolerable price increases as a result. Conversely, after the easing of sanctions, Iran believes its reinvigorated economy to be stronger and more resilient to any renewed sanctions that might be imposed in the future. At the same time, there is a belief that the simultaneous crises of Ukraine and the Islamic State have weakened the United States.

Arguing that the real issue is between Washington and Tehran, Dr Gary Samore, former White House Coordinator for Arms Control and Weapons of Mass Destruction, points to the bilateral talks as a "more 
sensible process for negotiation" than the $\mathrm{P} 5+1$, which he says holds "ceremonial sessions" which are too cumbersome to reach real decisions. ${ }^{61}$ In any case, the Ukraine crisis has undermined the $\mathrm{P} 5+1$ negotiation format; Iran can proceed with much more confidence, since if talks collapse, the United States and Europe would not be able to reach agreement within that framework on reconstructing sanctions.

Domestic support for Rouhani will continue to be fragile. Influential critics disapprove both of his nuclear and foreign policy ambitions, but also of his attempts to ease social and political conditions at home. ${ }^{62}$ Consideration of concessions to achieve nuclear agreement should include awareness of the potential adverse consequences of failure, including the potential for a more adversarial and unpredictable Iran as detailed above.

Supporting greater engagement between Iran and its neighboring Arab Gulf monarchies would be advantageous to the U.S. involvement in the region. The implications of an Iran-West detente are profound for the security strategies of the GCC states, a group of key U.S. allies deeply concerned about a potential threat from Iran. At the same time, it is essential to bear in mind that U.S. behavior toward Iran is watched very closely in Arab Gulf capitals, and perceived missteps - or compromises over Gulf security - would be likely to have immediate adverse consequences for U.S. relations in the region.

Iranian support for efforts against the Islamic State would undoubtedly boost U.S. efforts to subdue this threat. But temporary unity against a common enemy provides a fragile basis for a lasting relationship. Either side would view an alliance against the Islamic State with ambiguity, and all sides would retain their 
own motivations for independent action, leading to an alignment fraught with suspicion. ${ }^{63}$ A historical parallel is the Soviet Union finding, against its will, common cause with the Western Allies during World War II. The extent to which the Union of Soviet Socialist Republics was pursuing its own agenda became clear immediately after the common enemy was defeated, leading directly to an era of even greater confrontation.

\section{ENDNOTES}

1. Laura Rozen, “Obama Corresponds with Iran's Rouhani, Holds Out Hope for Nuclear Deal," Al-Monitor, September 15, 2013, available from backchannel.al-monitor.com/index. php/2013/09/6265/obama-says-exchanged-lettters-with-irans-rouhani/.

2. “Obama says Syria Deal Could Offer Lesson for Iran Talks," Reuters, September 15, 2014, available from www.reuters.com/ article/2013/09/15/us-syria-crisis-usa-idUSBRE98D09C20130915.

3. "Rouhani: Time Not Right for Another Phone Call with Obama," The Times of Israel, September 27, 2014, available from www.timesofisrael.com/rouhani-time-not-right-for-another-phone-callwith-obama.

4. "Rouhani Becomes Iran's New President," Press TV, June 15, 2013, available from www.presstv.ir/detail/2013/06/15/309169/ rohani-becomes-irans-new-president/, accessed on August 15, 2014.

5. "Iran Vote: Rouhani Vows Transparency on Nuclear Issue," BBC News website, June 17, 2013, available from www.bbc.co.uk/ news/world-middle-east-22940220, accessed on August 15, 2014.

6. "Hassan Rouhani Sworn in as President of Iran, Urging Moderation and Respect," The Guardian website, August 4, 2013, available from www.theguardian.com/world/2013/aug/04/hassanrouhani-sworn-in-president-iran, accessed on August 17, 2014. 
7. "Rouhani Stresses Regionalism in Iranian Foreign Policy," Al Monitor website, July 13, 2013, available from www.al-monitor. com/pulse/originals/2013/07/rouhani-stresses-regionalism-in-iranianforeign-policy.html\#, accessed on August 19, 2014.

8. Mark Mardell, “Obama's Thick Red Line on Syria," BBC News website, August 22, 2013, available from www.bbc.co.uk/ news/world-us-canada-23800031, accessed on August 19, 2014.

9. "Iranian Majlis Speaker: Syria Main Axis of Resistance against Zionist Regime," Iran state TV's (IRIB) website, July 22, 2014, available from tinyurl.com/nl2ok6q, accessed on September 20, 2014.

10. "President: Iran Not to Spare Any Effort to Liberate Holy Al-Quds," Iran's Iqna news website, September 1, 2014, available from iqna.ir/fa/News/1445335, accessed on September 20, 2014.

11. “Ahmadinejad's Remarks on Zionist Regime Enraged Supporters of Zionism," Iran's Fars News website, October 27, 2005, available from www.farsnews.com/newstext.php?nn=8408040372, accessed on September 21, 2014.

12. "Rouhani: Using Chemicals in Syria Strongly Condemned," Iran's Kaleme news website, August 24, 2013, available from www.kaleme.com/1392/06/02/ klm-155820/, accessed on August 24, 2014; "Rouhani: Iran to Do All Must Be Done to Prevent Syria War," Alahed news website, September 16, 2013, available from english.alahednews.com.lb/essaydetails.php? eid=24373\& cid=391, accessed on August 24, 2014.

13. “Iran's Ayatollah Ali Khamenei Warns U.S. Will 'Suffer Loss' Over Syria Intervention," Huffington Post website, September 5, 2013, available from www.huffingtonpost.com/2013/09/05/ iran-syria_n_3872149.html, accessed on August 24, 2014.

14. “Top Iranian Commander Says Attacking Syria Will Burn Israel Down," Iran's PRESS TV website, August 29, 2013, available from www.presstv.com/detail/2013/08/29/321084/any-syriaattack-sets-israel-on-fire/, accessed on August 25, 2014. 
15. "Iran Nuclear: Geneva Talks 'Something to Build On'," BBC News website, November 10, 2013, available from www. bbc.co.uk/news/world-middle-east-24887253, accessed on August 29, 2014.

16. "Supreme Leader: Nobody Should Call Our Negotiators Compromisers, These Are Our Own and Revolution's Children," Iran's Khabar (news) Online website, November 3, 2013, available from www.khabaronline.ir/detail/320604/Politics/leader, accessed on August 30, 2014.

17. "Americans Not Trustworthy, Unreasonable and Dishonest/ Interacting with World Detrimental If Derails Us from Path," Iran's Mehr News website, July 21, 2013, available from www. mehrnews.com/TextVersionDetail/2101717, accessed on August 30, 2014.

18. The full document can be seen at eeas.europa.eu/statements/ docs/2013/131124_03_en.pdf.

19. Professor Ghassan Salamé, Dean of the Paris School of International Affairs, Sciences Po, speaking at the International Institute for Strategic Studies, "Global Strategic Review," Oslo, Norway, September 20, 2014.

20. "How Did Pillars of Sanctions Crack?" Iran's Mehr News website, November 27, 2013, available from webzine.mehrnews. com/FullStory/News/?NewsId=10477, accessed on September 1, 2014.

21. "People Welcome Nuclear Negotiating Team at Mehrabad Airport," Iran's Khabar Online website, November 24, 2013, available from khabaronline.ir/detail/324297/Politics/diplomacy, accessed on September 1, 2014.

22. "Details of 'We Are Concerned' Gathering/Geneva Deal Targeting Essence of Islamic Revolution," Iran's Jahan News website, May 3, 2014, available from jahannews.com/vdcizvaput1aw52. cbct.html, accessed on September 1, 2014.

23. "Zarif's Response to Time of trip to Saudi Arabia," Iran's Al-Alam website, November 30, 2013, available from fa.alalam.ir/ news/1540151, accessed on September 2, 2014. 
24. "Iran and Turkey's Common Effort for Ceasefire in Syria," Deutsche Welle Persian website, November 27, 2013, available from tinyurl.com/qyptlb9, accessed on September 2, 2014.

25. Bradley Klapper, Matthew Lee, and Julie Pace, "Secret USIran Talks Set Stage for Nuke Deal," November 24, 2013, available from bigstory.ap.org/article/secret-us-iran-talks-set-stage-nukedeal, accessed on September 24, 2014.

26. For more detail, see Mohammed El-Katiri, "The Future of the Arab Gulf Monarchies in the Age of Uncertainties," Carlisle, PA: Strategic Studies Institute, U.S. Army War College, June 2013.

27. Damien McIlroy, "Iran Nuclear Deal: Saudi Arabia Warns It Will Strike Out on Its Own," The Daily Telegraph website, November 25, 2013, available from www.telegraph.co.uk/news/worldnews/middleeast/iran/10472538/Iran-nuclear-deal-Saudi-Arabiawarns-it-will-strike-out-on-its-own.html, accessed on September 24, 2014.

28. Sa'id Razavi-Faqih, "Prevention Better than Treatment," Iran's Sharq daily website, November 28, 2013, available from sharghdaily.ir/?News_Id=26463, accessed on September 2, 2014.

29. "British Embassy and Gholhak Garden in Tehran Attacked," BBC Persian website, November 29, 2011, available from www.bbc.co.uk/persian/iran/2011/11/111129_l10_britain_embassy_ tehran_protest.shtml, accessed on September 3, 2014.

30. Steven Erlanger, "Britain and Iran Move to Repair Diplomatic Relations," The New York Times website, October 8, 2013, available from www.nytimes.com/2013/10/09/world/middleeast/britain-and-iran-move-to-repair-diplomatic-relations.html?_r=0, accessed on September 4, 2014.

31. Saeed Kamali Dehghan, "Iran's Hassan Rouhani Has to Weigh Every Step at United Nations," The Guardian, available from www.theguardian.com/world/2014/sep/24/iran-hassan-rouhaniunited-nations. 
32. "Obama Gives Cautious Welcome to Rouhani as U.S. Lawmakers Vote for Tougher Sanctions," World ECR website, available from www.worldecr.com/obama-gives-cautious-welcome-torouhani-as-u-s-lawmakers-vote-for-tougher-sanctions/, accessed on September 5, 2014.

33. Andrew Kaczynski, "President Obama Speaks on the Phone with the Iranian President in Historic Call," Buzzfeed website, September 27, 2013, available from www.buzzfeed.com/ andrewkaczynski/obama-i-spoke-on-the-phone-with-the-iranianpresident\#4ex25pb, accessed on September 5, 2014; Erin McCann, "Hassan Rouhani Twitter Account Deletes Obama Tweets," The Guardian website, September 28, 2013, available from www. theguardian.com/world/2013/sep/28/hassan-rouhan-twitter-deletesobama, accessed on September 5, 2014.

34. "Supreme Leader: Some of what Happened in New York Not Right," Iran's Mehr News website, October 5, 2013, available from webzine.mehrnews.com/FullStory/News/?NewsId=8840, accessed on September 7, 2014.

35. "Statement by the President of the Islamic Republic of Iran at the 69th Session of the UN General Assembly," Iranian Presidential website, September 25, 2014, available from www. president.ir/en/81324.

36. International Institute for Strategic Studies, "Global Strategic Review."

37. "Photo: General Soleimani in Frontline of Fight against ISIS," Iran's Yalasarat website, September 4, 2014, available from www.yalasarat.com/vdciwpa3.t1aru2bcct.html, accessed on September 7, 2014.

38. "Militants Must Leave Syria: Iran's Zarif," Iran's PRESS TV website, January 25, 2014, available from www.presstv.com/detail/2014/01/25/347580/militants-must-leave-syria-iran-fm/, accessed on September 8, 2014.

39. "Iran FM Says Syria Extremism Threatens World," Iran's PRESS TV website, January 31, 2014, available from www.presstv. com/detail/2014/01/31/348646/syria-extremism-threatens-world-iran/, accessed on September 8, 2014. 
40. "Critical Situation in Syria Masterminded by US Official," The Islamic Republic News Agency, February 6, 2014, available from www.irna.ir/en/News/2627517/Politic/Critical_situation_in_Syria_ masterminded_by_US,_official, accessed on September 9, 2014.

41. "Major General Safavi Says Saudi Monarchy to be Destroyed," Iran's Mashreq News website, February 5, 2013, available from tinyurl.com/ognu8ba, accessed on September 9, 2014.

42. "Erdogan's Speech at Foreign Ministry Cancelled," Iran's Jahan News website, January 29, 2014, available from jahannews. com/vdciyuapzt1a5q2.cbct.html, accessed on September 10, 2014.

43. BBC Monitoring report: "Iran Web Users Comment on Reports of Slain Guards Commander in Syria," May 29, 2014, accessed on September 10, 2014.

44. Scott Peterson, "Iran Mourns 60th Officer to Die as 'Martyr' in Syria," Gulf News website, May 31, 2014, available from gulfnews.com/in-focus/syria/iran-mourns-60th-officer-to-die-asmartyr-in-syria-1.1341352, accessed on September 13, 2014.

45. "Body of Three Defenders of Zaynab's Shrine Laid to Rest in Mashhad," Iran's Tasnim News Agency, June 15, 2014, available from www.tasnimnews.com/Home/Single/401480, accessed on September 25, 2014.

46. "Larijani Warns MP to Exercise Caution in Comments on National Security," The Iranian Students' News Agency, February 23, 2014, available from tinyurl.com/q6gebnq, accessed on September 13, 2014.

47. Dexter Filkins, "The Shadow Commander," The New Yorker website, September 30, 2013, available from www.newyorker. com/magazine/2013/09/30/the-shadow-commander?currentPage=all, accessed on September 15, 2014.

48. "Iranian UAV Based on Captured U.S. Drone Filmed Over Damascus, Syria," YouTube website, November 18, 2013, available from www.youtube.com/watch?v=r_iRfZnOCZ4, accessed on September 10, 2014. 
49. Basma Atassi, "Al-Qaeda Says It Shot Down Syria Drone," Al Jazeera news website, December 7, 2013, available from www. aljazeera.com/news/middleeast/2013/12/al-qaeda-says-it-shot-downsyria-drone-2013127125556863281.html, accessed on September 11, 2014.

50. "Iran Determined to Continue Cooperation with IAEA: Spokeswoman," Iran's Tasnim News Agency, August 20, 2014, available from www.tasnimnews.com/English/Home/Single/467392, accessed on September 16, 2014.

51. "Salehi's Reaction to EBWs," Iran's Tebyan website, August 17, 2014, available from www.tebyan.net/newmobile.aspx/ comment/newindex.aspx?pid=283189, accessed on September 16, 2014.

52. “IAEA Envoy: Iran's Missile Program Redline in Talks with World Powers," Iran's Fars News Agency, August 18, 2014, available from english.farsnews.com/print.aspx?nn=13930527001536, accessed on September 18, 2014.

53. Dr Reza Simbor, "Amano, Mediator of Negotiations or Dealer for the West?," Iranian daily Hemayat website, August 17, 2014, available from www.hemayat.net/detail/News/3263, accessed on September 18, 2014.

54. "No Nuclear Deal with Sextet unless UNSC Bans Lifted: Iran FM," Iran's state TV IRIB website, August 18, 2014, available from english.irib.ir/news/item/194218-no-nuclear-deal-with-sextetunless-unsc-bans-lifted-iran-fm, accessed on September 18, 2014.

55. "Takht-Ravanchi: Deal Achievable by 24 November if P5+1 Avoids Wasting Time/No Agreement at Any Cost," Iran's Mehr News Agency website, August 18, 2014, available from www.mehrnews.com/detail/News/2352109, accessed on September 19, 2014.

56. "Motion for 60 Per Cent Enrichment Submitted to Majlis Presidium with 200 Signatures," Iran's Mehr News Agency website, December 29, 2013, available from www.mehrnews.com/detail/ News/2204410, accessed on September 19, 2014. 
57. “Time to Resolve Nuclear Issue Not Unlimited: Iran President," Iran's PRESS TV website, September 11, 2013, available from www.presstv.com/detail/2013/09/11/323278/time-to-settle-nissue -not-unlimited/, accessed on September 19, 2014.

58. John Kerry, "Iranian Nuclear Deal Still Is Possible, but Time Is Running Out," The Washington Post website, June 30, 2014, available from www.washingtonpost.com/opinions/iranian-nucleardeal-still-is-possible-but-time-is-running-out/2014/06/30/8510fbe20091-11e4-8fd0-3a663dfa68ac_story.html, accessed on September 20, 2014.

59. "Iran to Resume 20\% Enrichment If Nuclear Talks Fail: Araqchi," Iran's Press TV website, June 13, 2014, available from www.presstv.com/detail/2014/06/13/366750/iran-back-to-20-enrichment-if-talks-fail/, accessed on September 20, 2014.

60. "Leader Urges Serious Pursuit of 'Resistance Economy'," Iran's PRESS TV website, February 25, 2014, available from www. presstv.com/detail/2014/02/25/352188/leader-stresses-resistanceeconomy/, accessed on September 20, 2014.

61. International Institute for Strategic Studies, "Global Strategic Review."

62. "Iran: Hardline Anxiety over Rouhani Grows More Acute," BBC News, May 11, 2014, available from www.bbc.co.uk/ news/world-middle-east-27337623.

63. Peter Apps and Matt Spetalnick, "U.S., Iran Seek Common Ground Against Militants, but Doubts Persist," Reuters, September 23, 2014, available from www.reuters.com/article/2014/09/23/usiraq-crisis-usa-iran-idUSKCNOHI08G20140923. 


\title{
U.S. ARMY WAR COLLEGE
}

\author{
Major General William E. Rapp \\ Commandant
}

\section{***** \\ STRATEGIC STUDIES INSTITUTE and U.S. ARMY WAR COLLEGE PRESS}

Director

Professor Douglas C. Lovelace, Jr.

\author{
Director of Research \\ Dr. Steven K. Metz \\ Author \\ Mr. Keir Giles \\ Editor for Production \\ Dr. James G. Pierce \\ Publications Assistant \\ Ms. Rita A. Rummel
}

*****

Composition

Mrs. Jennifer E. Nevil 


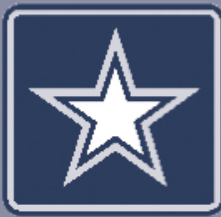

\section{U.S.ABinY}

THE

UNITED STATES

ARMY WAR COLLEGE

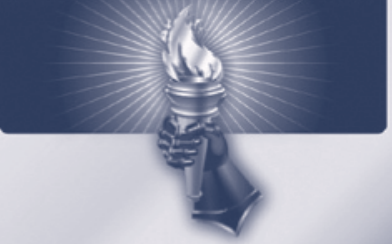

STR ENGTH $m$ WW ISDOM

FOR THIS AND OTHER PUBLICATIONS, VISIT US AT http://www.carlisle.army.mil/

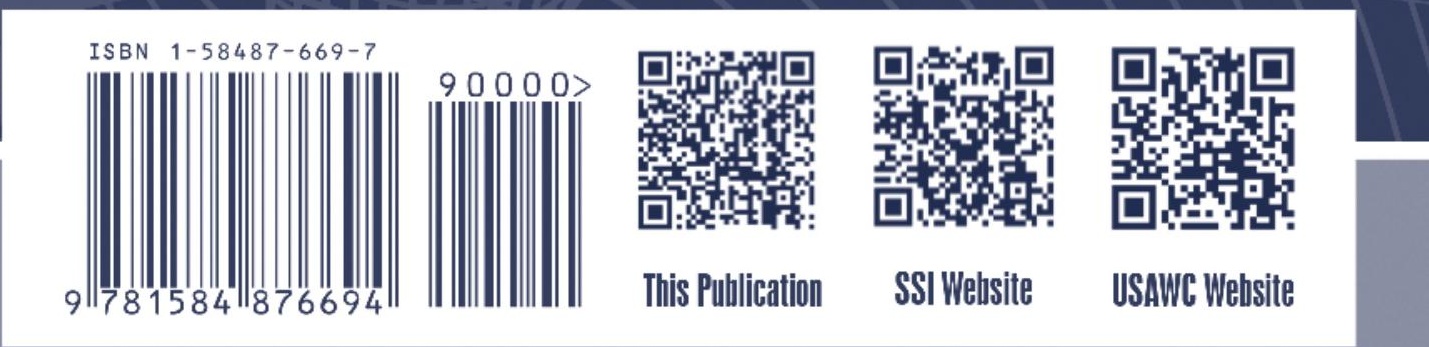

